\title{
Recurrent acute pancreatitis during a ketogenic diet-a case report and literature review
}

\author{
Joseph Choi ${ }^{1,2^{*}}$, Tayler L. Young ${ }^{3}$ and Lucas B. Chartier ${ }^{1,2}$
}

\begin{abstract}
Background: The ketogenic ("keto") diet has been gaining more attention lately in the medical literature and the lay media as a potentially effective method for weight control and management of type 2 diabetes. Though rare, there have been case reports of serious side effects. Here, we present a peculiar case of pancreatitis presumably associated with the ketogenic diet.

Case presentation: A 35-year-old man on a calorie-restricted ketogenic diet presented to the emergency department with weekly abdominal pain on Monday mornings, each time after dietary indiscretions ("cheat days") on the weekend. It was found that he had a clinical presentation consistent with acute pancreatitis with no associated alcohol use, hypertriglyceridemia, pancreatic obstruction, or other anatomic abnormalities. The patient's symptoms resolved with conservative management and progressive reintroduction of a standard diet.

Conclusion: This case indicates that the ketogenic diet could lower the threshold for acute pancreatitis, and that an episodic stressor may trigger an acute attack in the absence of traditional risk factors.
\end{abstract}

Keywords: Pancreatitis, Ketogenic diet, Low carbohydrate diet, Gastroenterology, Emergency department

\section{Background}

Low-carbohydrate diets for weight management have been described since the 1960s with the popularization of various diets such as the Atkins, Paleo, and ketogenic diets, and their popularity have been growing since [1]. Given the increasing prevalence of obesity [2] and diabetes [3], there has been an increasing interest in the role of carbohydrate consumption in the pathogenesis of these two conditions. Indeed, there is literature that suggests a low-carbohydrate diet is effective in managing these two conditions [4-8], but larger studies are

\footnotetext{
*Correspondence: joseph.choi@utoronto.ca

${ }^{1}$ Emergency Department, University Health Network, 200 Elizabeth Street, RFE - Ground Floor, 480, Toronto, Ontario M5G 2C4, Canada

${ }^{2}$ Division of Emergency Medicine, Department of Medicine, University of Toronto, C. David Naylor Building, 6 Queen's Park Crescent West, Third Floor, Toronto, Ontario M5S 3H2, Canada

Full list of author information is available at the end of the article
}

required to determine its long-term effects and generalizability [9].

While complications associated with the ketogenic diet are relatively rare [10], there have been reports of serious adverse events, including cardiac effects (such as dysrhythmias and sudden cardiac death) [11, 12], hepatitis, and ketoacidosis [13]. To date, there is only one published case report of acute pancreatitis associated with the use of a ketogenic diet for weight loss [14]. That case report presents an adult patient who had a severely elevated triglyceride level at the time of admission and pre-existing hypertriglyceridemia being controlled by medications.

The case we describe below is the first to describe a case of acute pancreatitis while on the ketogenic diet in the absence of severe hypertriglyceridemia.

C C The Author(s). 2021 Open Access This article is licensed under a Creative Commons Attribution 4.0 International License, which permits use, sharing, adaptation, distribution and reproduction in any medium or format, as long as you give appropriate credit to the original author(s) and the source, provide a link to the Creative Commons licence, and indicate if changes were made. The images or other third party material in this article are included in the article's Creative Commons licence, unless indicated otherwise in a credit line to the material. If material is not included in the article's Creative Commons licence and your intended use is not permitted by statutory regulation or exceeds the permitted use, you will need to obtain permission directly from the copyright holder. To view a copy of this licence, visit http://creativecommons.org/licenses/by/4.0/ The Creative Commons Public Domain Dedication waiver (http://creativecommons.org/publicdomain/zero/1.0/) applies to the data made available in this article, unless otherwise stated in a credit line to the data. 


\section{Case presentation}

A 35-year-old obese man presented to the emergency department (ED) with severe central abdominal pain with mild radiation to his back. He also had nausea and one episode of non-bilious, non-bloody vomiting. He denied fever or any change in his bowel habits. His review of systems was otherwise unremarkable. He denied any recent travel history, had not been exposed to any chemicals or exotic animals, and was in his usual state of health otherwise. He did not describe any infectious symptoms leading up to the presentation to the ED.

His past medical history was significant for hypertension, gout, type 2 diabetes mellitus, and dyslipidemia (elevated triglycerides, elevated total cholesterol, and high total cholesterol/HDL ratio). He was not on any medications, and these conditions were all managed through diet and lifestyle modifications under the supervision of his primary care provider (PCP). He had no surgical history. Although he reported being a heavy drinker in his early 20 s, he had cut back significantly for many years and only had three drinks in the month prior to presentation. $\mathrm{He}$ had a 15 pack-year smoking history, but he transitioned to smokeless tobacco products and nicotine replacement products over the preceding 3 years. He occasionally ingested marijuana recreationally but did not smoke it. He denied any other substance or supplement use.

On further questioning, the patient reported having been on a 2000-calorie-a-day ketogenic diet for the past 3 weeks, with "cheat days" on the weekends when he ate whatever he wanted. He did not track the exact content of his diet on these cheat days, but he consumed far more carbohydrates relative to his diet days. After these cheat days, he would resume his ketogenic diet the following Mondays. The diet was designed by himself with advice from Internet sources, and he had a discussion with his PCP who had given him his approval. The patient reported having experienced identical but less severe symptoms on Mondays since starting his diet (as it was on the day of this presentation). The first Monday he experienced these symptoms, he had presented to a walk-in clinic but no definitive diagnosis was made. The second episode of pain occurred the following Monday, which was more severe and sustained. This led him to present to the ED.

The patient's initial vital signs included a blood pressure of $155 / 101 \mathrm{mmHg}$, a heart rate of 77 , a respiratory rate of 18 , an oxygen saturation of $95 \%$ on room air, and he was afebrile. They remained similar and stable throughout the patient's ED course.

On examination, the patient appeared well but in pain, rated as 10/10. He was not jaundiced, and his mucous membranes were moist. His cardiorespiratory examination was unremarkable. The patient's abdomen was non-tympanic with normal bowel sounds and no skin discoloration. The patient was exquisitely tender in the epigastrium, but it was otherwise soft without peritoneal signs. He had neither right upper quadrant tenderness nor Murphy's sign. Point-of-care (i.e., bedside) ultrasound showed no abdominal free fluid, no gallstones, and no other sonographic signs of cholecystitis.

The primary differential diagnosis considerations included hepatobiliary causes (such as biliary colic, choledocholithiasis, and acute cholecystitis), pancreatic causes (such as acute pancreatitis), and gastric causes (such as gastritis, gastric and duodenal ulcers) given the upper abdominal tenderness and vomiting. An atypical presentation of acute coronary syndrome was also considered, but was less likely given the history and physical examination findings. Similarly, thoracic and pulmonary diagnoses were entertained, but did not seem likely given the details of the case.

Table 1 Patient's laboratory profile on admission to the ED. Abnormal lab values are in bold

\begin{tabular}{|c|c|c|}
\hline Blood test & Value & Normal range \\
\hline \multicolumn{3}{|l|}{ Complete blood count } \\
\hline Hemoglobin & $151 \mathrm{~g} / \mathrm{L}$ & $140-180 \mathrm{~g} / \mathrm{L}$ \\
\hline White blood cells & $15.4 \times 10^{\wedge} 9 / \mathrm{L}$ & $4-11 \times 10^{\wedge} 9 / L$ \\
\hline Platelets & $223 \times 10 \wedge 9 / L$ & $150-400 \times 10 \wedge 9 / L$ \\
\hline Hematocrit & 0.43 & $0.42-0.54$ \\
\hline $\mathrm{Na}$ & $139 \mathrm{mmol} / \mathrm{L}$ & $135-145 \mathrm{mmol} / \mathrm{L}$ \\
\hline K & $4.7 \mathrm{mmol} / \mathrm{L}$ & $3.2-5.0 \mathrm{mmol} / \mathrm{L}$ \\
\hline $\mathrm{Cl}$ & $103 \mathrm{mmol} / \mathrm{L}$ & $100-110 \mathrm{mmol} / \mathrm{L}$ \\
\hline $\mathrm{HCO} 3$ & $23 \mathrm{mmol} / \mathrm{L}$ & 23-29 mmol/L \\
\hline $\mathrm{Cr}$ & $83 \mu \mathrm{mol} / \mathrm{L}$ & $64-110 \mu \mathrm{mol} / \mathrm{L}$ \\
\hline eGFR & $>104 \mathrm{~mL} / \mathrm{min} / \mathrm{m}^{2}$ & $>60 \mathrm{~mL} / \mathrm{min} / \mathrm{m}^{2}$ \\
\hline Glucose & $9.3 \mathrm{mmol} / \mathrm{L}$ & 3.8-7.0 mmol/L \\
\hline $\mathrm{Ca}$ & $2.49 \mathrm{mmol} / \mathrm{L}$ & 2.20-2.62 mmol/L \\
\hline $\mathrm{Mg}$ & $0.70 \mathrm{mmol} / \mathrm{L}$ & $0.70-1.10 \mathrm{mmol} / \mathrm{L}$ \\
\hline PO4 & $0.98 \mathrm{mmol} / \mathrm{L}$ & $0.80-1.40 \mathrm{mmol} / \mathrm{L}$ \\
\hline Aspartate aminotransferase (AST) & $34 \mathrm{U} / \mathrm{L}$ & $5-34 \mathrm{U} / \mathrm{L}$ \\
\hline Alanine aminotransferase (ALT) & $43 \mathrm{U} / \mathrm{L}$ & $7-40 \mathrm{U} / \mathrm{L}$ \\
\hline Alkaline phosphatase (ALP) & $70 \mathrm{U} / \mathrm{L}$ & 40-150 U/L \\
\hline Bilirubin & $11 \mu \mathrm{mol} / \mathrm{L}$ & $<22 \mu \mathrm{mol} / \mathrm{L}$ \\
\hline Lipase & $2283 \mathrm{U} / \mathrm{L}$ & $<60 \mathrm{U} / \mathrm{L}$ \\
\hline Troponin & $2 \mathrm{ng} / \mathrm{L}$ & $<26 \mathrm{ng} / \mathrm{L}$ \\
\hline Lactate & $0.8 \mathrm{mmol} / \mathrm{L}$ & $<2 \mathrm{mmol} / \mathrm{L}$ \\
\hline \multicolumn{3}{|l|}{ IgG subclass analysis } \\
\hline $\lg G 1$ & 5.85 & $3.82-9.29$ \\
\hline $\lg G 2$ & 2.25 & $2.42-7.00$ \\
\hline $\lg G 3$ & 0.48 & $0.22-1.76$ \\
\hline $\operatorname{lgG} 4$ & 0.076 & $0.039-0.864$ \\
\hline
\end{tabular}


The patient's point-of-care glucose testing was 9.3 $\mathrm{mmol} / \mathrm{L}$. His electrocardiogram showed normal sinus rhythm. The patient's bloodwork on presentation to the ED is shown in Table 1 . The only significant abnormalities were an extremely high lipase (2283 U/L), an elevated glucose $(9.3 \mathrm{mmol} / \mathrm{L})$, and an elevated white blood cell count $\left(15.4 \times 10^{\wedge} 9\right.$ cells $\left./ \mathrm{L}\right)$.

A comprehensive ultrasound of the abdomen showed severe fatty infiltration of the liver, a normal gallbladder with no gallstones, non-dilated bile ducts, and patent portal and hepatic veins. The pancreas was incompletely visualized due to bowel gas and body habitus but it was described as ill-defined and heterogeneous, but without peripancreatic fluid or other ductal abnormality.

Given the patient's characteristic signs and symptoms and a significantly elevated lipase, the diagnosis of acute pancreatitis was confirmed, and the patient was admitted to the general surgery service.

On the ward, the patient's pain was controlled with opioids, and he received anti-emetics and intravenous fluids. Initially set at nil per os, his diet was slowly advanced until he was able to tolerate food without pain, and he was discharged home 2 days later. The patient's lipase level was never measured again, but all other previously performed blood results were repeated and returned to the normal range within $24 \mathrm{~h}$ of admission.

Table 2 compares his lipid and metabolic profile from 3 weeks prior to the hospital admission (and prior to starting the ketogenic diet) to the values obtained on his presentation to ED. It is interesting to note that over the 3 weeks of the ketogenic diet, his metabolic profile generally improved despite the relative increase of calories derived from fat.

The patient continued to do well after his discharge from the hospital. He abandoned a strict ketogenic diet and reintroduced carbohydrates into his diet, while increasing his fruits and vegetable intake. He had not had any further episodes of acute pancreatitis 6 months after his index admission.

\section{Discussion and conclusion}

The average American diet contains 250-350 g of carbohydrates per day, much of which is comprised of refined starches and added sugars [15]. Ketogenic diets typically restrict carbohydrate intake to less than $50 \mathrm{~g} /$ day [16]. This reduction in carbohydrate intake leads to drops in insulin secretion, which in turn decreases lipogenesis and fat deposition. In this setting, the body adapts by activating lipolysis and transitions from glucose to fat as its primary energy source. Metabolism of fatty acids produces acetoacetate and beta-hydroxybutyrate, collectively known as ketone bodies, and the resulting state is referred as ketosis [16].

Acute pancreatitis typically involves inappropriate activation of pancreatic zymogens, leading to acinar cell damage, leakage of these enzymes into the tissues of the pancreas, and pancreatic autodigestion [17]. There are established risk factors and causes for pancreatitis, such as gallstones, alcohol use, and hypertriglyceridemia, that are well described offenders [18].

On literature review, six studies outlining seven cases were found in which acute pancreatitis developed in association with ketogenic diet. Of the 68 papers identified and reviewed, no case was found to describe cases of pancreatitis with normal or nearnormal triglyceride levels. The characteristics of these studies are outlined in Table 3. The literature search was conducted with Medline. The following Boolean approach was found to yield the most relevant and comprehensive results: "pancreatitis" AND "ketogenic." All six studies included surmised that hyperlipidemia secondary to ketogenic diet contributed to the onset of acute pancreatitis. In most cases, triglyceride levels at the time of pancreatitis onset were not disclosed.

Our case report describes the first case report of a patient developing acute pancreatitis in association with the ketogenic diet with near-normal triglyceride levels at the time of diagnosis. The majority of cases in the literature describe pancreatitis associated with the ketogenic

Table 2 Metabolic profile performed immediately prior to the start of the ketogenic diet compared with the day of ED visit

\begin{tabular}{llll}
\hline Test & Normal range & $\mathbf{3}$ weeks prior (before ketogenic diet) & Day of ED presentation \\
\hline Hemoglobin A1C & $<6 \%$ & $7 \%$ & $6.2 \%$ \\
Cholesterol & Variable & $5.88 \mathrm{mmol} / \mathrm{L}$ & $3.94 \mathrm{mmol} / \mathrm{L}$ \\
Triglyceride & $<2.2 \mathrm{mmol} / \mathrm{L}$ & $8.53 \mathrm{mmol} / \mathrm{L}$ & $2.51 \mathrm{mmol} / \mathrm{L}$ \\
$\mathrm{HDL}-$ cholesterol & Variable & $0.65 \mathrm{mmol} / \mathrm{L}$ & $0.60 \mathrm{mmol} / \mathrm{L}$ \\
$\mathrm{LDL}-$ cholesterol & Variable & $\mathrm{N} / \mathrm{A}^{\mathrm{a}}$ & $2.19 \mathrm{mmol} / \mathrm{L}$ \\
Non-HDL cholesterol & Variable & $5.23 \mathrm{mmol} / \mathrm{L}$ & $3.3 \mathrm{mmol} / \mathrm{L}$ \\
Total cholesterol/HDL ratio & Variable & 9.0 & 6.6
\end{tabular}

${ }^{a}$ Invalid result when triglycerides are too high 
Table 3 Studies examining the association of pancreatitis and the ketogenic diet

\begin{tabular}{|c|c|c|c|c|c|c|c|c|}
\hline Study & Study type & $\begin{array}{l}\text { Number } \\
\text { of } \\
\text { patients } \\
\text { in study }\end{array}$ & $\begin{array}{l}\text { Number of } \\
\text { cases of } \\
\text { acute } \\
\text { pancreatitis }\end{array}$ & $\begin{array}{l}\text { Age, } \\
\text { year }\end{array}$ & $\begin{array}{l}\text { Indication for } \\
\text { ketogenic diet }\end{array}$ & $\begin{array}{l}\text { Triglycerides at } \\
\text { time of } \\
\text { diagnosis of } \\
\text { acute } \\
\text { pancreatitis }\end{array}$ & $\begin{array}{l}\text { Ketogenic diet } \\
\text { duration }\end{array}$ & $\begin{array}{l}\text { Outcome of patients } \\
\text { with acute pancreatitis }\end{array}$ \\
\hline $\begin{array}{l}\text { Stewart } \\
\text { et al. [19] }\end{array}$ & Case report & 1 & 1 & 9 & $\begin{array}{l}\text { Glucose } \\
\text { transport } \\
\text { protein } \\
\text { syndrome }\end{array}$ & N/A & 8.5 years & Death \\
\hline $\begin{array}{l}\text { Mackay } \\
\text { et al. [20] }\end{array}$ & $\begin{array}{l}\text { Retrospective } \\
\text { chart review }\end{array}$ & 26 & 1 & $\begin{array}{l}\text { Median } \\
\text { age in } \\
\text { study } \\
\text { was } 6.1\end{array}$ & $\begin{array}{l}\text { Refractory } \\
\text { epilepsy }\end{array}$ & N/A & $\begin{array}{l}\text { Median } \\
\text { duration of } \\
\text { treatment in } \\
\text { study was } 9 \\
\text { months }\end{array}$ & $\begin{array}{l}\text { Early cessation of } \\
\text { ketogenic diet, treatment } \\
\text { details unknown }\end{array}$ \\
\hline $\begin{array}{l}\text { Mori et al. } \\
\text { [21] }\end{array}$ & Case report & 1 & 1 & 5.7 & $\begin{array}{l}\text { Refractory } \\
\text { epilepsy }\end{array}$ & N/A & 5.25 years & Death \\
\hline $\begin{array}{l}\text { Lyczkowski } \\
\text { et al. [22] }\end{array}$ & $\begin{array}{l}\text { Retrospective } \\
\text { study }\end{array}$ & 71 & 2 & $\begin{array}{l}\text { Mean } \\
\text { age in } \\
\text { study } \\
\text { was } 6.52\end{array}$ & $\begin{array}{l}\text { Refractory } \\
\text { epilepsy }\end{array}$ & N/A & 4 months & $\begin{array}{l}\text { Early cessation of } \\
\text { ketogenic diet, treatment } \\
\text { details unknown }\end{array}$ \\
\hline $\begin{array}{l}\text { Sofou et al. } \\
\text { [23] }\end{array}$ & $\begin{array}{l}\text { Longitudinal } \\
\text { cohort study }\end{array}$ & 19 & 1 & 4.2 & $\begin{array}{l}\text { Pyruvate } \\
\text { dehydrogenase } \\
\text { complex } \\
\text { deficiency }\end{array}$ & N/A & 15 months & $\begin{array}{l}\text { Early cessation of } \\
\text { ketogenic diet, treatment } \\
\text { details unknown }\end{array}$ \\
\hline $\begin{array}{l}\text { Buse et al. } \\
{[14]}\end{array}$ & Case report & 1 & 1 & 42 & Weight loss & $\begin{array}{l}>25.86 \mathrm{mmol} / \mathrm{L} \\
\text { (normal }<2.2 \\
\mathrm{mmol} / \mathrm{L} \text { ) }\end{array}$ & Several days & $\begin{array}{l}\text { 13-day hospital admission } \\
\text { with discharge in good } \\
\text { condition and normalized } \\
\text { triglycerides }\end{array}$ \\
\hline
\end{tabular}

diet in children with metabolic syndromes or refractory epilepsy. A particularly interesting feature of this patient's case is that the recurrent episodes of presumed pancreatitis seemed to be triggered by relatively higher carbohydrate intake and higher caloric intake during his cheat days, as opposed to the sustained higher fat intake during his diet maintenance days. When he would go back to his carbohydrate-restricted, high-fat intake days, the symptoms seemed to resolve on their own over the course of the week. Unfortunately, the patient did not keep a diary to track his exact food intake over these cheat days, and simply stated that he ate "everything bad" without adhering to any limits.

The patient's triglyceride levels (along with glycated hemoglobin and cholesterol levels) had improved significantly on the day of his presentation to the ED compared to his fasting blood work done by his PCP prior to starting the diet. If the increased proportional fat intake of the ketogenic diet itself were to blame for his recurring bouts, the patient would have had a history of pancreatitis prior to the start of the diet when his fasting triglyceride levels were even higher.

As the popularity of low-carbohydrate diets increase, healthcare providers must be vigilant of potential complications presenting to the emergency department. This case emphasizes lifestyle and dietary factors that contribute to acute disease states and presentations and may be missed by providers during their history taking. While this case did not have any of the risk factors or triggers that are classically associated with acute pancreatitis, we hypothesize that the cyclic and significant fluctuations in dietary composition (and therefore large swings in pancreatic secretory activity) may have contributed to the development of acute pancreatitis in this patient.

\section{Abbreviations \\ ED: Emergency department; PCP: Primary care provider; WBC: White blood cells; AST: Aspartate aminotransferase; ALT: Alanine aminotransferase; \\ ALP: Alkaline phosphatase}

\section{Acknowledgements}

Not applicable

\section{Authors' contributions}

LBC conducted the patient interview to gather data surrounding the case presentation and illness. JC, TLY, and LBC were all involved in drafting and editing of the manuscript. All authors approve of the final manuscript.

\section{Funding \\ This article did not receive any additional funding.}

\section{Availability of data and materials}

All relevant raw data (lab values, imaging findings) has been included in this manuscript.

\section{Declarations}

Ethics approval and consent to participate

Verbal and written consent was obtained from the patient during the postadmission interview by LBC to share the details of his illness for the purposes of a case report. There were no requirements for institutional ethics board review or approval for this case report. 


\section{Consent for publication}

Consent was obtained from the patient to share the details of his illness for the purposes of a case report, as described above. Verbal and written consent was obtained from the patient.

\section{Competing interests}

The authors declare that they have no competing interests.

\section{Author details}

'Emergency Department, University Health Network, 200 Elizabeth Street, RFE - Ground Floor, 480, Toronto, Ontario M5G 2C4, Canada. ${ }^{2}$ Division of Emergency Medicine, Department of Medicine, University of Toronto, C. David Naylor Building, 6 Queen's Park Crescent West, Third Floor, Toronto, Ontario M5S 3H2, Canada. ${ }^{3}$ Faculty of Medicine, University of Ottawa, 451 Smyth Road, Ottawa, Ontario K1H 8M5, Canada.

Received: 25 July 2021 Accepted: 27 August 2021

Published online: 15 September 2021

\section{References}

1. Bravata DM, Sanders L, Huang J, Krumholz HM, Olkin I, Gardner CD, et al. Efficacy and safety of low-carbohydrate diets. JAMA. 2003;289(14):1837. Available from: http://jama.jamanetwork.com/article.aspx?doi=https://doi. org/10.1001/jama.289.14.1837

2. Hales CM, Carroll MD, Fryar CD, Ogden CL. Prevalence of Obesity Among Adults and Youth: United States, 2015-2016. NCHS Data Brief. 2017:(288):1-8.

3. Guariguata L, Whiting DR, Hambleton I, Beagley J, Linnenkamp U, Shaw JE. Global estimates of diabetes prevalence for 2013 and projections for 2035. Diabetes Res Clin Pract. 2014;103(2):137-49. Available from: https:// linkinghub.elsevier.com/retrieve/pii/S0168822713003859. https://doi.org/10.1 016/j.diabres.2013.11.002

4. Foster GD, Wyatt HR, Hill JO, McGuckin BG, Brill C, Mohammed BS, et al. A randomized trial of a low-carbohydrate diet for obesity. N Engl J Med 2003; 348(21):2082-2090. Available from: http://www.nejm.org/doi/abs/https://doi. org/10.1056/NEJMoa022207

5. Samaha FF, lqbal N, Seshadri P, Chicano KL, Daily DA, McGrory J, Williams T, Williams M, Gracely EJ, Stern L A low-carbohydrate as compared with a lowfat diet in severe obesity. N Engl J Med 2003;348(21):2074-2081. Available from: http://www.nejm.org/doi/abs/https://doi.org/10.1056/NEJMoa022637

6. Brehm BJ, Seeley RJ, Daniels SR, D'Alessio DA. A randomized trial comparing a very low carbohydrate diet and a calorie-restricted low fat diet on body weight and cardiovascular risk factors in healthy women. J Clin Endocrinol Metab 2003;88(4):1617-1623. Available from: https://academic.oup.com/ jcem/article-lookup/doi/https://doi.org/10.1210/jc.2002-021480

7. Yancy WS, Foy M, Chalecki AM, Vernon MC, Westman EC. A lowcarbohydrate, ketogenic diet to treat type 2 diabetes. Nutr Metab (Lond). 2005;2(1):34. Available from: https://nutritionandmetabolism.biomedcentral. com/articles/https://doi.org/10.1186/1743-7075-2-34

8. Hussain TA, Mathew TC, Dashti AA, Asfar S, Al-Zaid N, Dashti HM. Effect of lowcalorie versus low-carbohydrate ketogenic diet in type 2 diabetes. Nutrition. 2012;28(10):1016-21. Available from: https://inkinghub.elsevier.com/retrieve/ pii/S0899900712000731. https://doi.org/10.1016/..nut.2012.01.016.

9. Joshi S, Ostfeld RJ, McMacken M. The ketogenic diet for obesity and diabetes—enthusiasm outpaces evidence. JAMA Intern Med. 2019;179(9): 1163 Available from: https://jamanetwork.com/journals/jamainterna Imedicine/fullarticle/2737919.

10. Weber DD, Aminzadeh-Gohari S, Tulipan J, Catalano L, Feichtinger RG, Kofler B. Ketogenic diet in the treatment of cancer - Where do we stand? Mol Metab. 2020;33:102-21. https://doi.org/10.1016/j.molmet.2019.06.026. Epub 2019 Jul 27.

11. Doksöz Ö, Güzel O, Yılmaz Ü, İsgüder R, Çeleğen K, Meșe T. Dispersion durations of P-wave and QT interval in children treated with a ketogenic diet. Pediatr Neurol. 2014;50(4):343-6. Available from: https://linkinghub. elsevier.com/retrieve/pii/S0887899413007194. https://doi.org/10.1016/j.pedia trneurol.2013.12.005

12. Bank IM, Shemie SD, Rosenblatt B, Bernard C, Mackie AS. Sudden cardiac death in association with the ketogenic diet. Pediatr Neurol. 2008;39(6):42931. Available from: https://linkinghub.elsevier.com/retrieve/pii/S08878994 08003998. https://doi.org/10.1016/j.pediatrneurol.2008.08.013.

13. Kang HC, Chung DE, Kim DW, Kim HD. Early- and late-onset complications of the ketogenic diet for intractable epilepsy. Epilepsia 2004;45(9):1116-
1123. Available from: https://onlinelibrary.wiley.com/doi/https://doi.org/1 0.1111/j.0013-9580.2004.10004.x

14. Buse GJ, Riley KD, Dress CM, Neumaster TD. Patient with gemfibrozilcontrolled hypertriglyceridemia that developed acute pancreatitis after starting ketogenic diet. Curr Surg. 2004;61(2):224-6. Available from: https:// linkinghub.elsevier.com/retrieve/pii/S0149794403001594. https://doi.org/10.1 016/S0149-7944(03)00159-4.

15. U.S. Department of Health and Human Services and U.S. Department of Agriculture. Dietary Guidelines for Americans 2015-2020 Eighth Edition. 8th ed: Skyhorse Publishing Inc.; 2015. p. 144. Available from: https://health.gov/ our-work/food-nutrition/previous-dietary-guidelines/2015

16. Paoli A, Rubini A, Volek JS, Grimaldi KA. Beyond weight loss: a review of the therapeutic uses of very-low-carbohydrate (ketogenic) diets. Eur J Clin Nutr. 2013;67(8):789-96. Available from: http://www.nature.com/articles/ejcn2 013116. https://doi.org/10.1038/ejcn.2013.116.

17. Bhatia $\mathrm{M}$, Wong FL, Cao $\mathrm{Y}$, Lau HY, Huang J, Puneet $\mathrm{P}$, et al. Pathophysiology of acute pancreatitis. Pancreatology. 2005:5(2-3):132-44. Available from: https://inkinghub.elsevier.com/retrieve/pii/S14243903 0580050X. https://doi.org/10.1159/000085265.

18. Whitcomb DC. Acute pancreatitis. N Engl J Med 2006;354(20):2142-2150 Available from: http://www.nejm.org/doi/abs/https://doi.org/10.1056/ NEJMcp054958

19. Stewart WA, Gordon K, Camfield P. Acute pancreatitis causing death in a child on the ketogenic diet. J Child Neurol 2001;16(9):682-682. Available from: http://journals.sagepub.com/doi/https://doi.org/10.1177/088307380101 600910

20. Mackay MT, Bicknell-Royle J, Nation J, Humphrey M, Harvey AS. The ketogenic diet in refractory childhood epilepsy. J Paediatr Child Health 2005;41(7):353-357. Available from: https://onlinelibrary.wiley.com/doi/ https://doi.org/10.1111/j.1440-1754.2005.00630.x

21. Mori M, Kumada T, Inoue K, Nozaki F, Matsui K, Maruo Y, et al. Ketogenic diet for refractory epilepsy with MEHMO syndrome: caution for acute necrotizing pancreatitis. Brain Dev. 2021;43(6):724-8. Available from: https:// linkinghub.elsevier.com/retrieve/pii/S0387760421000267. https://doi.org/10.1 016/j.braindev.2021.02.002.

22. Lyczkowski DA, Pfeifer HH, Ghosh S, Thiele EA. Safety and tolerability of the ketogenic diet in pediatric epilepsy: effects of valproate combination therapy. Epilepsia 2005;46(9):1533-1538. Available from: https://onlinelibrary. wiley.com/doi/https://doi.org/10.1111/j.1528-1167.2005.22705.x

23. Sofou K, Dahlin M, Hallböök T, Lindefeldt M, Viggedal G, Darin N. Ketogenic diet in pyruvate dehydrogenase complex deficiency: short- and long-term outcomes. J Inherit Metab Dis 2017:40(2):237-245. Available from: http://doi. wiley.com/https://doi.org/10.1007/s10545-016-0011-5

\section{Publisher's Note}

Springer Nature remains neutral with regard to jurisdictional claims in published maps and institutional affiliations.

Ready to submit your research? Choose BMC and benefit from:

- fast, convenient online submission

- thorough peer review by experienced researchers in your field

- rapid publication on acceptance

- support for research data, including large and complex data types

- gold Open Access which fosters wider collaboration and increased citations

- maximum visibility for your research: over $100 \mathrm{M}$ website views per year

At BMC, research is always in progress.

Learn more biomedcentral.com/submissions 